\title{
NICKEL INCORPORATION IN Fe(II, III) HYDROXYSULFATE GREEN RUST: EFFECT ON CRYSTAL LATTICE SPACING AND OXIDATION PRODUCTS ${ }^{(1)}$
}

\author{
Lucia Helena Garófalo Chaves ${ }^{(2)}$, Joan Elizabeth Curry ${ }^{(3)}$, David \\ Andrew Stone $^{(4)}$, Michael D. Carducci ${ }^{(5)} \&$ Jon Chorover ${ }^{(6)}$
}

\begin{abstract}
SUMMARY
$\mathrm{Ni}(\mathrm{II})-\mathrm{Fe}(\mathrm{II})-\mathrm{Fe}$ (III) layered double hydroxides (LDH) or Ni-containing sulfate green rust (GR2) samples were prepared from $\mathrm{Ni}$ (II), $\mathrm{Fe}$ (II) and $\mathrm{Fe}$ (III) sulfate salts and analyzed with $X$ ray diffraction. Nickel is readily incorporated in the GR2 structure and forms a solid solution between GR2 and a Ni(II)-Fe(III) LDH. There is a correlation between the unit cell $a$-value and the fraction of $\mathrm{Ni}$ (II) incorporated into the Ni(II)-GR2 structure. Since there is strong evidence that the divalent/trivalent cation ratio in GR2 is fixed at 2 , it is possible in principle to determine the extent of divalent cation substitution for Fe(II) in GR2 from the unit cell $a$-value. Oxidation forms a mixture of minerals but the LDH structure is retained if at least $20 \%$ of the divalent cations in the initial solution are $\mathrm{Ni}(\mathrm{II})$. It appears that $\mathrm{Ni}(\mathrm{II})$ is incorporated in a stable LDH structure. This may be important for two reasons, first for understanding the formation of LDHs, which are anion exchangers, in the natural environment. Secondly, this is important for understanding the fate of transition metals in the environment, particularly in the presence of reduced Fe compounds.
\end{abstract}

Index terms: isomorphous substitution, layered double hydroxide, LDH, X ray diffraction

\footnotetext{
(1) Received for publication in february 2008 and aproved in july 2009.

(2) Full Professor at the Department of Agricultural Engineering. Universidade Federal de Campina Grande - UFCG. Caixa Postal 10087, CEP 58109-970 Campina Grande (PB). E-mail: lhgarofalo@hotmail.com

(3) Associate Professor at the University of Arizona, Department of Soil, Water and Environmental Science. Tucson, Az, 85721, USA. E-mail: curry@ag.arizona.edu

(4) Graduate Student at the University of Arizona, Department of Soil, Water and Environmental Science. Tucson, Az, 85721, USA. E-mail: dstone@u.arizona.edu

(5) University of Arizona, Department of Chemistry. Tucson, Az, 85721,USA. E-mail: carducci@email.arizona.edu

(6) Professor at the University of Arizona, Department of Soil, Water and Environmental Science. Tucson, Az, 85721,USA. Email: chorover@cals.arizona.edu
} 


\title{
RESUMO: INCORPORAÇÃO DE NÍQUEL EM Fe (II-III) GRENN RUST HIDROXISULFATO: EFEITO SOBRE A ESTRUTURA CRISTALINA E PRODUTOS DE OXIDAÇÃO
}

\begin{abstract}
Amostras de hidróxidos de dupla camada (HDC), ou "sulfate green rust"(GR2), contendo $\mathrm{Ni}$ foram preparadas utilizando-se sulfatos de $\mathrm{Ni}(\mathrm{II}), \mathrm{Fe}$ (II) e Fe(III) e analisadas por difração de raios $X$. O Ni está incorporado na estrutura do GR2 e forma um sólido entre GR2 e um HDC contendo $\mathrm{Ni}(\mathrm{II})-\mathrm{Fe}(\mathrm{III})$. Há correlação entre os valores de "a" da célula unitária e os da fração de Ni(II) incorporado na estrutura do Ni(II)-GR2. Desde que haja forte evidência de que a razão entre os cátions divalente/trivalente no GR2 seja igual a 2, é possível, a princípio, determinar a extensão da substituição do cátion divalente por $\mathrm{Fe}(I I)$ no GR2 a partir dos valores de "a" da célula unitária do cristal. Sob o efeito da oxidação, é formada uma mistura de minerais, porém a estrutura do HDC não é alterada se pelo menos $20 \%$ dos cátions divalentes na solução inicial forem de Ni(II). Isso parece indicar que o Ni(II) está incorporado à estrutura estável do HDC, o que é importante por duas razões: para entender a formação dos HDC, os quais são trocadores aniônicos em condições naturais no meio ambiente; e para entender o destino dos metais de transição no ambiente, particularmente na presença de compostos de Fe na forma reduzida.
\end{abstract}

Termos de indexação: substituição isomórfica, hidróxido de dupla camada, HDC, difração de raios $X$.

\section{INTRODUCTION}

The substitution of $\mathrm{Ni}$ in reduced and poorly crystalline Fe oxides can alter the transformation rate and ultimately the specific end products formed during transformation of these minerals into more stable phases (Cornell et al., 1992; Chung et al., 2002). For instance, Ni substitution retards the transformation of ferrihydrite to more stable $\mathrm{Fe}$ oxides such as goethite and hematite (Ford et al., 1999). It has been shown that $\mathrm{Ni}$ readily substitutes $\mathrm{Fe}$ (III) in goethite due to the similarity in cation size but this produces a local distortion in the structure (Manceau et al., 2000, Carvalho e Silva et al., 2003) which is thought to limit the substitution to $\sim 5 \mathrm{~mol} \%$ (Singh et al., 2002). Nickel is an important alloying element in austenitic stainless steel that reportedly contributes to corrosion resistance (Wambach et al., 2002).

Nickel also can be incorporated in the structure of reduced $\mathrm{Fe}$ oxides such as green rust. This has implications for the fate of transition metals in the environment. For instance, Parmar et al. (2001) have shown that $\mathrm{Ni}$ in solution is immobilized in the green rust that forms as a result of microbially mediated $\mathrm{Fe}(\mathrm{III})$ reduction. Inoue et al. (2008) have shown that $\mathrm{Ni}$ enhances the formation of goethite in the oxidation of green rust in aqueous solution. Nickel is also associated with the green rust formed during $\mathrm{Fe}$ oxidation in permeable reactive barriers (Bartzas et al., 2006). Chaves et al. (2007) showed that green rust is probably more efficient in removing Ni from the environment by coprecipitation during mineral formation than by adsorption to already formed green rust. Green rust is a Fe(II)-Fe(III) hydroxide that consists of positively charged brucite-like layers, alternating with anions and water molecules. The general composition is $\left[\mathrm{Fe}(\mathrm{III})_{(6-\mathrm{x})} \mathrm{Fe}(\mathrm{III})_{\mathrm{x}}(\mathrm{OH})_{12}\right]^{\mathrm{x}+}\left[(\mathrm{A})_{\mathrm{x} /}\right.$ $\left.\mathrm{n} \cdot \mathrm{yH}_{2} \mathrm{O}\right]^{\mathrm{x}}$ - where $\mathbf{x}=0.9-4.2, \mathrm{~A}$ is an $\mathrm{n}$-valent anion, e.g., $\mathrm{CO}_{3}{ }^{2-}, \mathrm{Cl}^{-}$or $\mathrm{SO}_{4}{ }^{2-}$ and y denotes the varying amounts of interlayer water. Two types of green rust can be distinguished: green rust one (GR1), with a rhombohedral unit cell, and green rust two (GR2) with a hexagonal cell. GR2 contains sulfate or other tetrahedral anions such as selenate and perchlorate in the interlayer spaces. The sulfate GR2 structure has been studied in detail and it is known that a long range order exists among the $\mathrm{Fe}(\mathrm{III})$ ions in the brucitelike sheet and $\mathrm{SO}_{4}{ }^{2-}$ anions in the interlayer spaces (Génin, 2004). In pure GR2, each Fe(III) is surrounded by six $\mathrm{Fe}$ (II) ions, so the ratio of divalent/trivalent ions equal to 2 .

More generally, green rust is a member of the family of minerals called "layered double hydroxides $(\mathrm{LDH})$ ", which have been the subject of much interest due to potential applications as anion exchangers (Rives, 2001). Known as anionic clays, LDHs are, in general, brucite-like sheets containing a mixture of divalent (e.g. $\mathrm{Mg}, \mathrm{Mn}, \mathrm{Fe}, \mathrm{Co}, \mathrm{Ni}, \mathrm{Cu}, \mathrm{Zn}$ ) and trivalent (e.g. $\mathrm{Al}, \mathrm{Mn}, \mathrm{Fe}, \mathrm{Co}, \mathrm{Ni}, \mathrm{Cr}, \mathrm{Ga}$ ) cations. There is wide variety in the potential composition and application of LDHs.

Green rusts are found naturally as corrosion products of Fe metal (Refait et al., 2003a) and as minerals in hydromorphic soils (Génin et al., 2001). They can be synthesized in the laboratory by partial oxidation of $\mathrm{Fe}$ (II) or by reactions of $\mathrm{Fe}$ (II) and $\mathrm{Fe}(\mathrm{III})$ salts in aqueous solutions (Géhin et al., 2002). Green rusts, unlike most Fe oxides, have a large internal surface area and consequently great reactivity. They represent reactive ion exchangers and sorbents (Hansen et al., 2001). The amphoteric surface hydroxyl groups lead to the sorption of heavy metals 
(cations) as well as of inorganic anions, e.g. silicate, arsenate and selenate. In addition, cations such as $\mathrm{Cu}(\mathrm{II}), \mathrm{Ni}(\mathrm{II}), \mathrm{Zn}(\mathrm{II}), \mathrm{Cd}(\mathrm{II}), \mathrm{Co}(\mathrm{II})$ and $\mathrm{Mg}(\mathrm{II})$ may substitute $\mathrm{Fe}$ (II) isomorphically during green rust formation. It has been shown that $\mathrm{Ni}$ (II) can substitute Fe(II) in both GR1(Cl-) (Refait \& Génin, 1993, 1997; Refait et al., 1994, 1998) and GR2 (Refait et al., 1990, 2005). Oxidation, depending on the extent of $\mathrm{Ni}$ incorporation, $\mathrm{Ni}(\mathrm{II})-\mathrm{Fe}(\mathrm{III})$ produces LDHs stable against further oxidation. While green rust would probably not be used as an agent to decontaminate soil, this incorporation of cationic inorganic contaminants into the structure of reduced green rust and LDHs could provide an effective means to sequester contaminants in the subsurface under appropriate conditions. It is therefore important to understand the potential of green rust to incorporate cations such as Ni during formation as well as the potential to release these same cations as the Fe(II) is converted to $\mathrm{Fe}(\mathrm{III})$ on exposure to oxidizing conditions in the environment.

Green rusts are unstable in oxidizing conditions and their rapid reaction with atmospheric $\mathrm{O}_{2}$ results in the formation of ferrihydrite $\left(\mathrm{Fe}_{5} \mathrm{HO}_{8} \cdot 4 \mathrm{H}_{2} \mathrm{O}\right)$, goethite $(\alpha-\mathrm{FeOOH})$, akaganeite $(\beta-\mathrm{FeOOH})$, lepidocrocite $(\gamma$ $\mathrm{FeOOH})$, hematite $\left(\alpha-\mathrm{Fe}_{2} \mathrm{O}_{3}\right)$ maghemite $\left(\gamma-\mathrm{Fe}_{2} \mathrm{O}_{3}\right)$ or magnetite $\left(\mathrm{Fe}_{3} \mathrm{O}_{4}\right)$, depending on $\mathrm{pH}$, solution composition, oxidant, oxidation rate, and the dehydration degree and rate (Lin et al., 1996; LoyauxLawniczak et al., 2000). Refait \& Génin (1997) prepared Ni(II)-Fe(II)-Fe(III) hydroxychloride LDHs by aerial oxidation of mixed $\mathrm{Ni}$ (II)-Fe(II)-hydroxides. They found that the final oxidation products depended on the initial $\mathrm{Fe} / \mathrm{Ni}$ ratio. In the absence of $\mathrm{Ni}$, green rust oxidized to lepidocrocite and the $\mathrm{LDH}$ structure was lost. For $\mathrm{Fe} / \mathrm{Ni}>5 / 3$ both lepidocrocite and some $\mathrm{Ni}(\mathrm{II})-\mathrm{Fe}(\mathrm{III})$ hydroxychloride were detected by $\mathrm{X}$ ray diffraction. For Fe/Ni between $1 / 3$ and 5/3, only the hydroxychloride LDH was obtained. Since LDHs contain a mixture of divalent and trivalent cations in a brucite-like sheet, if enough $\mathrm{Ni}$ is present in divalent sites, the LDH structure is preserved on oxidation of structural $\mathrm{Fe}(\mathrm{II})$. In the current study we further investigated substitution of Ni(II) in sulfate GR2 and the oxidation products from exposure to air. The specific research objective is to determine the effect of $\mathrm{Ni}$ (II) incorporation on the GR2 crystal structure and to determine how $\mathrm{Ni}$ (II) affects the oxidation products by directly precipitating nickelous-GR2 from a mixture of $\mathrm{Fe}(\mathrm{II}), \mathrm{Ni}$ (II) and $\mathrm{Fe}(\mathrm{III})$ sulfate salts in anoxic conditions followed by aerial oxidation of the dried samples.

\section{MATERIALS AND METHODS}

GR2 is very sensitive to air oxidation, and was therefore synthesized in an anoxic chamber (glove box). Sulfate GR2, hereafter referred to as GR2, was prepared by coprecipitating a mixture of $\mathrm{Fe}(\mathrm{II}), \mathrm{Ni}(\mathrm{II})$ and $\mathrm{Fe}(\mathrm{III})$ sulfate salts with $\mathrm{Na}$ hydroxide, following the method described by Géhin et al. (2002).

Briefly, ferrous sulfate heptahydrate $\mathrm{FeSO}_{4} .7 \mathrm{H}_{2} \mathrm{O}$, $\mathrm{Ni}$ sulfate hexahydrate $\mathrm{NiSO}_{4} \cdot 6 \mathrm{H}_{2} \mathrm{O}$ and ferric sulfate pentahydrate $\mathrm{Fe}_{2}\left(\mathrm{SO}_{4}\right)_{3} .5 \mathrm{H}_{2} \mathrm{O}$ were dissolved in $100 \mathrm{~mL}$ of $\mathrm{N}_{2}$-purged deionized water. A [(Fe(II) + $\mathrm{Ni}(\mathrm{II}))] /[\mathrm{Fe}(\mathrm{III})]$ ratio of 3 was used with $\{[\mathrm{Fe}(\mathrm{II})]+$ $[\mathrm{Ni}(\mathrm{II})]+[\mathrm{Fe}(\mathrm{III})]\}=0.2 \mathrm{~mol} \mathrm{~L}^{-1}$. The ratio $\mathrm{P}=[\mathrm{Fe}(\mathrm{II})] /$ [Ni(II)] varied from $100 \% \mathrm{Fe}$ (II) to $100 \% \mathrm{Ni}$ (II).

Samples were prepared with P equal to 100/0, 90/10, 80/20, 70/30, 60/40, 30/70, 20/80, 10/90, and 0/100. The samples 50/50 and 40/60 were not prepared. The initial concentration of $\mathrm{Fe}(\mathrm{III})$ in all samples was $0.05 \mathrm{~mol} \mathrm{~L}^{-1}$. Magnetic stirring ensured fast and complete dissolution. Then, $100 \mathrm{~mL}$ of $0.6 \mathrm{~mol} \mathrm{~L}^{-1}$ $\mathrm{NaOH}$, corresponding to a final $\left[\mathrm{OH}^{-}\right] /\{[\mathrm{Fe}(\mathrm{II})]+$ $[\mathrm{Ni}(\mathrm{II})]+[\mathrm{Fe}(\mathrm{III})]\}$ ratio of $3 / 2$, was added to the solution under continuous stirring. After one hour, the $\mathrm{pH}$ was measured (6.36-6.85), stirring was stopped and the sample aged in the flask for $24 \mathrm{~h}$. The sample was then centrifuged and the supernatant decanted and stored for further analysis. The precipitate was subsequently washed twice with $\mathrm{N}_{2}$-purged deionized water. The decanted solutions from the washing process were also collected and stored for further analysis. A small amount of nitric acid was then added to the decanted supernatant solutions in order to avoid the precipitation of Fe(III) oxyhydroxides. The decanted supernatants were analyzed for Fe(II) after reaction with ferrozine according to Stookey (1970) using an UV-Vis recording spectrophotometer (Shimadzu UV 3101 PC).

Total Fe was determined by inductively coupled plasma mass spectrometry (ICP-MS) and Fe(III) was then calculated by difference. The Ni(II) concentration was determined using an atomic absorption spectrophotometer. The GR2 precipitate was dried and ground to powder in the glove box. X ray diffraction (XRD) was used to characterize the dried samples. XRD analysis was performed on a Philips X'Pert Pro MPD Instrument using $\mathrm{CuK} \alpha(1.5418 \AA$ ) radiation and an X'Celerator RTMS array detector. The samples were placed in air-tight glass vials prior to removal from the glove box. For each sample, the air-tight vial was opened and approximately $0.5 \mathrm{~g}$ sample material was backloaded into a round $15 \mathrm{~mm}$ diameter sample holder (depth $5 \mathrm{~mm}$ ), which was immediately placed on the XRD facility and scanned for $11 \mathrm{~min}$. Air exposure during this transfer was less than $5 \mathrm{~min}$.

Preliminary tests showed that GR2 samples had identical patterns when prepared as described and then dispersed in deoxygenated glycerin and smeared on glass plates. Only minor color changes, if any, were observed in both cases. The goniometer calibration was checked daily by comparison of a standard $\mathrm{Si}$ powder disk (mounted similarly) to known values. The scan performed covered 5 to $75^{\circ} 2 \theta$ using unfiltered $\mathrm{Cu}$ radiation, with interpolated step sizes of $0.017^{\circ}$, 
and $20 \mathrm{~s} /$ step counting time. The sample was spun at a rate of 1 revolution per $4 \mathrm{~s}$. A fixed divergence slit of $1 / 4^{\circ}$ was used.

After an initial XRD characterization the samples were stored in weigh boats, open to the atmosphere to observe the role of $\mathrm{Ni}$ in the transformation of the GR2 samples. The sample was repacked for further scans. XRD was then repeated several times over a period of 7 to 45 days.

\section{RESULTS AND DISCUSSION}

Nickel-substituted GR2 (Ni(II)-GR2) samples with varying $\mathrm{Ni}$ amounts were prepared and analyzed with XRD. In the studies of Refait \& Génin $(1993,1997)$ and Refait et al. (1990, 1994, 1998, 2005) the green rust samples were prepared by partially oxidizing mixed $\mathrm{Fe}(\mathrm{II})$ and $\mathrm{Ni}(\mathrm{II})$ salt solutions. In this resdearch the samples were prepared without oxidation by directly mixing $\mathrm{Fe}(\mathrm{II}), \mathrm{Fe}(\mathrm{III})$ and $\mathrm{Ni}(\mathrm{II})$ salts in an anoxic environment. All fresh Ni(II)-GR2 samples appeared homogeneous and green in color, except for the sample containing $\mathrm{Ni}$ and $\mathrm{Fe}$ (III) only, which was yellow, the characteristic color of the Ni(II)-Fe(III) LDH, hydrohonessite (Nickel \& Wildman, 1981). The cation composition of the samples was inferred indirectly from the difference between the cation concentrations in the initial solutions and the solution (including washing solutions) unvaried after precipitation of the solid material. The relative molar amounts of $\mathrm{Fe}(\mathrm{II}), \mathrm{Ni}(\mathrm{II})$ and $\mathrm{Fe}(\mathrm{III})$ in the samples normalized by $\mathrm{Fe}(\mathrm{III})$ are given in table 1 .

Even though the divalent/trivalent cation ratio in the initial solution was fixed at 3 , with the exception of sample $\mathrm{P}=80 / 20$, the ratio in the precipitated samples from $\mathrm{P}=100 / 0$ to $20 / 80$ was closer to 2 which

Table 1. Relative molar amounts of Fe(II), Ni(II) and Fe(III) and the divalent/trivalent ratio in the $\mathrm{Ni}(\mathrm{II})-\mathrm{GR} 2$ samples as a function of the divalent ion ratio $\mathrm{Fe}(\mathrm{II}) / \mathrm{Ni}(\mathrm{II})$ in the starting solution

\begin{tabular}{cllcc}
\hline Fe(II)/Ni(II) & $\mathbf{F e}(\mathbf{I I})$ & $\mathbf{N i ( I I )}$ & $\mathbf{F e}(\mathbf{I I I})$ & $\begin{array}{c}\text { (Fe(II) + } \\
\mathbf{N i}(\mathbf{I I}) \mathbf{F e}(\mathbf{I I I})\end{array}$ \\
\hline $100 / 0$ & 1.95 & 0 & 1.00 & 1.95 \\
$90 / 10$ & 1.70 & 0.249 & 1.00 & 1.95 \\
$80 / 20$ & 1.88 & 0.570 & 1.00 & 2.45 \\
$70 / 30$ & 1.27 & 0.720 & 1.00 & 1.99 \\
$60 / 40$ & 1.01 & 0.867 & 1.00 & 1.88 \\
$30 / 70$ & 0.727 & 1.17 & 1.00 & 1.90 \\
$20 / 80$ & 0.530 & 1.32 & 1.00 & 1.85 \\
$10 / 90$ & 0.280 & 1.39 & 1.00 & 1.67 \\
$0 / 100$ & 0 & 1.45 & 1.00 & 1.45 \\
\hline
\end{tabular}

is the value for GR2. It is suspected that the anomalously high value for the $\mathrm{P}=80 / 20$ sample is due to an error in measuring the $\mathrm{Fe}$ (II) concentration in the supernatant. The ratio decreases at high Ni contents $(\mathrm{P}=10 / 90$ and $0 / 100)$ which could indicate the formation of a separate $\mathrm{Fe}(\mathrm{III})$ phase in addition to the LDH.

Figure 1 shows the XRD patterns for all fresh $\mathrm{Ni}$ (II)-GR2 samples as a function of the initial solution $\mathrm{Fe}(\mathrm{II}) / \mathrm{Ni}(\mathrm{II})$ ratio. The interplanar distances $(c)$, the size of the unit cell along the a-axis $(a)$, the volume of the unit cell $(V)$ and the size of the particles along the c axis, $D_{c}$, for each sample are listed in table 2 . The errors noted in table 2 are due to least squares refinement of observed peak positions to the cell given for the GR2 structure.

The XRD plot for GR2 with no Ni $(P=100 / 0)$ is shown at the bottom of figure 1 as reference. Six peaks were observed that matched those reported for GR2. These are $2 \theta=8.05^{\circ}, 16.21^{\circ}, 24.35^{\circ}, 32.55^{\circ}, 33.57^{\circ}$ and $36.54^{\circ}$. One peak for magnetite was also identified at $2 \theta=35.4^{\circ}$. The GR2 c-value was $1.0974 \pm$ $0.0007 \mathrm{~nm}$ and the a-value $0.3173 \pm 0.0001 \mathrm{~nm}$ in excellent agreement with the values reported by Bernal et al. (1959) for GR2. Even as Ni was added in increasing amounts, the characteristic green rust peaks persisted suggesting that $\mathrm{Ni}$ is incorporated into the brucite layer structure. Most likely Fe(II) was replaced by $\mathrm{Ni}$ (II) resulting in $\mathrm{Ni}$ (II)-GR2, which is isomorphous to GR2 (Refait et al., 1994). The divalent

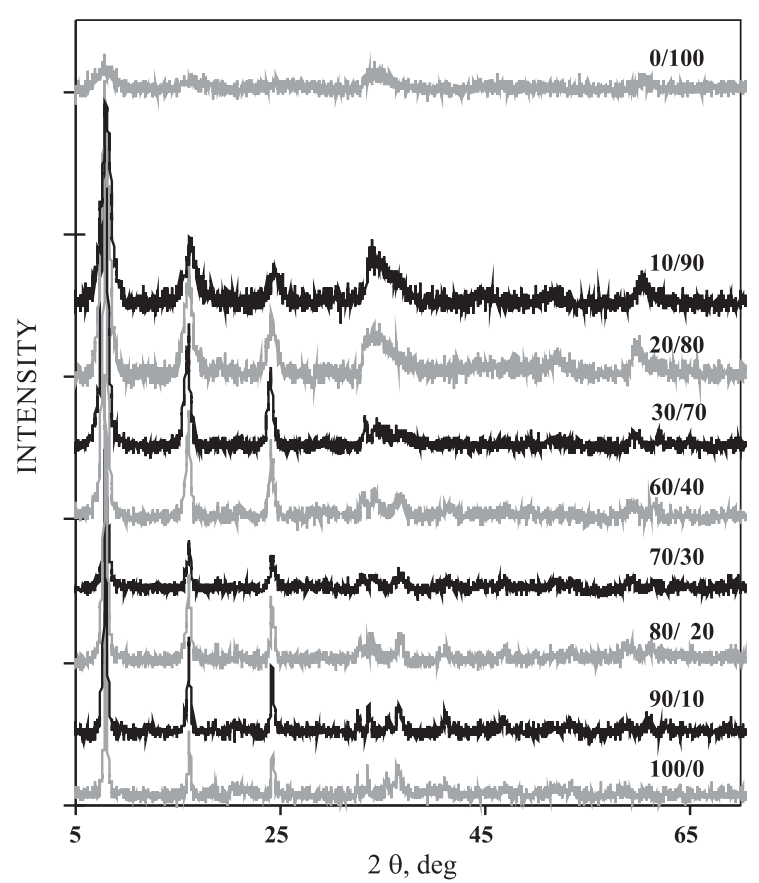

Figure 1. X ray diffraction patterns of the initial $\mathrm{Ni}$ (II)-GR2 products obtained in anoxic conditions as a function of the $\mathrm{Fe}(\mathrm{II}) / \mathrm{Ni}$ (II) ratio of the starting solution. 
mole fraction in the solid as a function of the divalent mole fraction or divalent fraction in solution is plotted in figure 2 .

The 001, 002 and 003 peaks at $8^{\circ}, 16^{\circ}$ and $24^{\circ} 2 \theta$ are easily identified for all samples that contain Fe(II). Peak broadening indicates a decrease in crystallinity with increasing incorporation of $\mathrm{Ni}$. In the sample containing only $\mathrm{Ni}$ and $\mathrm{Fe}$ (III) the three characteristic peaks nearly disappear suggesting a role for $\mathrm{Fe}(\mathrm{II})$ in promoting the crystallinity of the brucite-layer structure under these conditions.

Table 2 shows the lattice values of all samples in this study as calculated from the XRD patterns with the exception of the sample containing only $\mathrm{Ni}$ and Fe(III), which was poorly crystalline.

In all cases the $c$-value was near the value of $1.097 \mathrm{~nm}$, for pure GR2. While there is some variation there is no apparent correlation with the $\mathrm{Fe}(\mathrm{II}) / \mathrm{Ni}(\mathrm{II})$ initial ratio, indicating that in this case either the

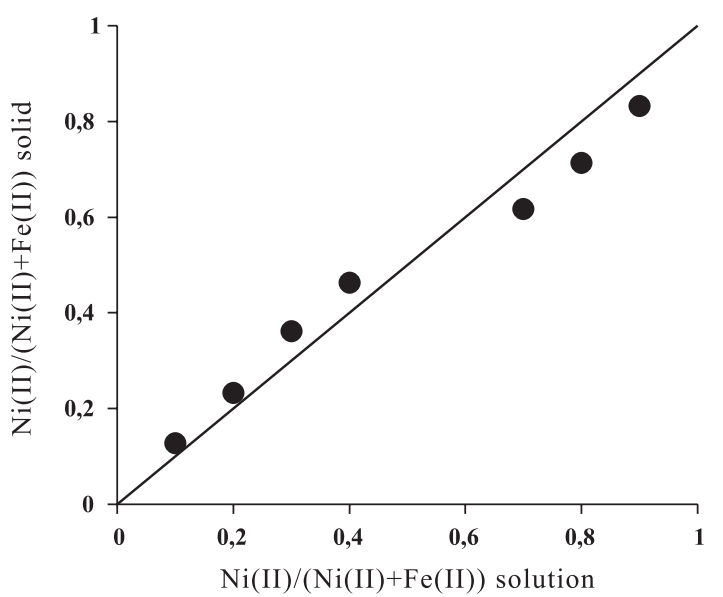

Figure 2. Divalent mole fraction of $\mathrm{Ni}(\mathrm{II}), \mathrm{Ni}(\mathrm{II}) /$ ( $\mathrm{Ni}(\mathrm{II})+\mathrm{Fe}(\mathrm{II}))$, in solid vs initial solution phase. accuracy was insufficient to distinguish a trend or the c-value was not sensitive to substitution of $\mathrm{Fe}(\mathrm{II})$ by $\mathrm{Ni}(\mathrm{II})$. In contrast, the variation in the lateral dimension of the brucite-like sheet, given by the $a$ value, decreased systematically with increasing $\mathrm{Ni}$ content. This is consistent with the fact that Fe(II) is larger than $\mathrm{Ni}(\mathrm{II})$. More quantitatively, the $a$-value for $\mathrm{Ni}(\mathrm{OH})_{2}$, which is the pure Ni brucite sheet, was $0.3126 \mathrm{~nm}$ (Greaves \& Thomas, 1986) whereas the $a$ value for the pure ferrous brucite sheet, $\mathrm{Fe}(\mathrm{OH})_{2}$, was larger at $0.3262 \mathrm{~nm}$ (Bernal et al., 1959). The substitution of $\mathrm{Fe}$ (II) by $\mathrm{Ni}(\mathrm{II})$ in any brucite-like compound should therefore result in a decrease in the lateral dimension of the unit cell.

It appears that these samples represent a solid solution with the end members GR2 and a Ni(II)-Fe(III) $\mathrm{LDH}$ with formula $\mathrm{Ni}_{4} \mathrm{Fe}_{2}(\mathrm{OH})_{12} \mathrm{SO}_{4} \mathrm{nH}_{2} \mathrm{O}$. With the exception of the $\mathrm{P}=80 / 20$ sample, the calculated divalent/trivalent ratios for samples $\mathrm{P}=100 / 0$ through $\mathrm{P}=20 / 80$ were near 2 , which is the value for GR2. However, the divalent/trivalent cation ratio decreased for samples containing higher $\mathrm{Ni}$ amounts. One possibility is that the divalent/trivalent cation ratio is 2 for the $\mathrm{LDH}$ and another Fe oxide phase forms. However, no discrete Fe oxide phase is detectable by $\mathrm{XRD}$. Another possibility is that the ratio decreased to $\sim 1.5$ for the poorly crystalline Ni(II)-Fe(III) LDH. It is known that the divalent/trivalent cation ratio in LDHs can vary widely with values typically being between 2 and 3 (Drits \& Bookin, 2001). Since XRD was not sufficient to eliminate the possibility that another mineral, e.g., a poorly crystalline Fe oxide is present (Refait et al., 2005) it was not possible to confirm either of these possibilities. However, the trend in the lattice values with increasing Ni content suggested that the lattice parameters for the poorly crystalline $\mathrm{Ni}$ (II)-Fe(III) mineral should be $\mathrm{c} \sim 1.09 \mathrm{~nm}$ and $\mathrm{a} \sim 0.309 \mathrm{~nm}$. This correlates well with the lattice values for hydrohonessite $(\mathrm{c}=1.08 \mathrm{~nm}$ and $\mathrm{a}=$ $0.309 \mathrm{~nm}$ ), a naturally occurring $\mathrm{Ni}(\mathrm{II})-\mathrm{Fe}(\mathrm{III}) \mathrm{LDH}$

Table 2. Interplanar distances $d_{001}(c)$, size of the unit cell along the axis $(a)$, volume of the unit cell ( $\left.V\right)$ and thickness $\left(D_{c}\right)$ of crystallites along the c hexagonal axis as determined by the Scherrer formula in the $\mathrm{Ni}(\mathrm{II})-\mathrm{GR} 2$ samples, as a function of the divalent ion ratio in the starting solution, $\mathrm{Fe}(\mathrm{II}) / \mathrm{Ni}$ (II)

\begin{tabular}{|c|c|c|c|c|}
\hline $\mathrm{Fe}(\mathrm{II}) / \mathrm{Ni}(\mathrm{II})$ & $c$ & $a$ & $V / 10^{6} \mathrm{pm}^{3}$ & $D_{\mathrm{c}}$ \\
\hline & 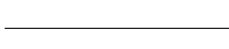 & & & $\mathrm{nm}$ \\
\hline $100 / 0$ & $1.0974( \pm 0.0007)$ & $0.3173( \pm 0.0001)$ & 95.676 & 41.96 \\
\hline $90 / 10$ & $1.1003( \pm 0.0006)$ & $0.3165( \pm 0.0007)$ & 95.470 & 31.89 \\
\hline $80 / 20$ & $1.1046( \pm 0.0001)$ & $0.3151( \pm 0.0001)$ & 94.988 & 26.57 \\
\hline $70 / 30$ & $1.0991( \pm 0.0008)$ & $0.3133( \pm 0.0001)$ & 93.452 & 20.98 \\
\hline $60 / 40$ & $1.0963( \pm 0.0002)$ & $0.3134( \pm 0.0004)$ & 93.243 & 20.44 \\
\hline $30 / 70$ & $1.1097( \pm 0.0003)$ & $0.3115( \pm 0.0001)$ & 93.276 & 15.94 \\
\hline $20 / 80$ & $1.10( \pm 0.01)$ & $0.3105( \pm 0.0005)$ & 92.093 & 11.07 \\
\hline $10 / 90$ & $1.09( \pm 0.01)$ & $0.3094( \pm 0.0007)$ & 90.679 & 9.60 \\
\hline
\end{tabular}


containing sulfate as the interlayer anion (Nickel \& Wildman, 1981). The formula for hydrohonessite is $\mathrm{Ni}_{6} \mathrm{Fe}_{2}(\mathrm{OH})_{16} \mathrm{SO}_{4} \mathrm{nH}_{2} \mathrm{O}$ (Frost et al., 2003) with a divalent/trivalent cation ratio of 3 , in contrast to the ratio of 2 , which is more consistent with our data for $\mathrm{Ni}(\mathrm{II})-\mathrm{GR} 2$ up to $\mathrm{P}=30 / 70$.

In foundation work used to derive the ideal hydrohonessite formula, Bish \& Livingstone (1981) analyzed naturally occurring hydrohonessite samples and found the divalent/trivalent cation ratio to be $\sim 2.5$. The authors concluded that, analogously to reevesite $\left(\mathrm{Ni}_{6} \mathrm{Fe}_{2}(\mathrm{OH})_{16} \mathrm{CO}_{3} 4 \mathrm{H}_{2} \mathrm{O}\right)$, the $\mathrm{Ni}(\mathrm{II}) / \mathrm{Fe}(\mathrm{III}) \mathrm{LDH}$ containing carbonate as the interlayer anion, the ideal divalent/trivalent cation ratio for hydrohonessite is most likely also 3 , resulting in a formula of $\mathrm{Ni}_{6} \mathrm{Fe}_{2}(\mathrm{OH})_{16} \mathrm{SO}_{4} \mathrm{nH}_{2} \mathrm{O}$. In contrast, Refait et al. (2005) recently synthesized a Ni(II)-Fe(III) LDH with a $\mathrm{Ni}(\mathrm{II}) / \mathrm{Fe}$ (III) ratio equal to 2 which is isomorphous with $\mathrm{GR} 2, \mathrm{Ni}_{4} \mathrm{Fe}_{2}(\mathrm{OH})_{12} \mathrm{SO}_{4} \mathrm{nH}_{2} \mathrm{O}$. The reported lattice values were $\mathrm{a}=0.320 \pm 0.003 \mathrm{~nm}$ and $\mathrm{c}=1.094$ $\pm 0.004 \mathrm{~nm}$, which are the same as GR2, indicating that the effect of the substitution of $\mathrm{Ni}$ (II) for $\mathrm{Fe}(\mathrm{II})$ on the a-value was not detectable in this study. Given that our synthesis method is very similar to that used by Refait et al. (2005) it is likely that the samples synthesized here have a $\mathrm{Ni}(\mathrm{II}) / \mathrm{Fe}(\mathrm{III})$ ratio closer to 2 than to 3 but the a-values are consistent with the end member of the solid solution, being hydrohonessite. Further work is needed to clarify the variation of the $\mathrm{Ni}(\mathrm{II}) / \mathrm{Fe}(\mathrm{III})$ ratio for $\mathrm{Ni}(\mathrm{II})-\mathrm{Fe}$ (III) LDHs.

The systematic decrease in the lateral unit cell size with increasing $\mathrm{Ni}$ content also suggests a quantitative correlation between this parameter and the degree of Ni substitution. Figure 3 shows the avalue determined from the XRD patterns as a function of the Ni fraction in the solid samples calculated based on the molar ratios given in table 1 .

There is a linear relationship between the a-value and the $\mathrm{Ni}$ fraction in the samples suggesting that

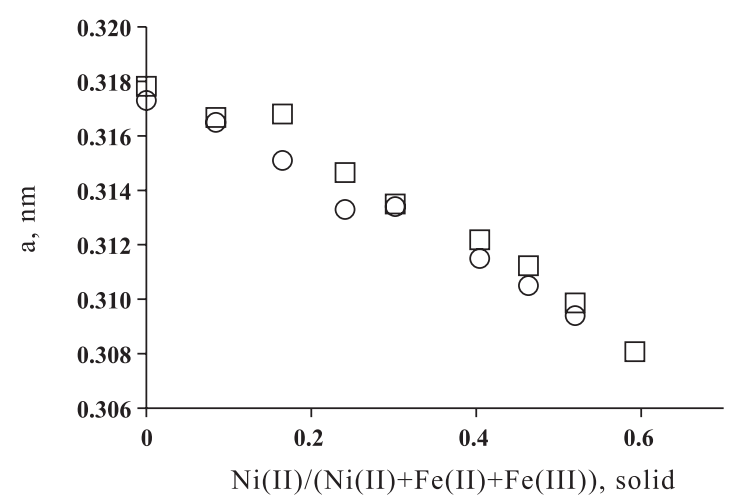

Figure 3. Reduction of the unit cell edge length $a$ of the Ni(II)-GR2 samples as a function of $\mathrm{Ni(II)}$ content. Circles denote $a$-values determined by XRD measurements. Squares denote $a$-values determined by equation (1).
Vegard's rule (Vegard, 1921) holds for Ni substitution in GR2. Vegard's rule is a long-standing empirical principle in chemical crystallography that has guided structural studies of solid solutions of isomorphous salts. It presumes that the lattice constant varies linearly with the composition of mixed crystals and implies a similarity of structure and symmetry of the mixed crystals and the end members (Gopalan \& Kahr, 1993). Vegard's rule has been shown to apply quite generally to substitution in a number of LDHs (Drits \& Bookin, 2001; Tichit et al., 2002). Most commonly, allowing the divalent/trivalent cation ratio to vary, the $\mathrm{Ni}$ (II)-GR2 can be considered a mixture of three pure end-member brucite-like species, namely $\mathrm{Ni}(\mathrm{OH})_{2}, \mathrm{Fe}(\mathrm{OH})_{2}$ and $\mathrm{Fe}(\mathrm{OH})_{3}$ (Bourrié et al., 2004). In this case the Vegard correlation for the ternary mixture can be written as:

$$
\begin{gathered}
a_{\mathrm{Ni}-\mathrm{GR} 2}=f_{\mathrm{Fe}(\mathrm{II})} a_{\mathrm{Fe}(\mathrm{OH})_{2}}+f_{\mathrm{Fe}(\mathrm{III})} a_{\mathrm{Fe}(\mathrm{OH})_{3}}+ \\
f_{\mathrm{Ni} i} a_{\mathrm{NI}(\mathrm{OH})_{2}}
\end{gathered}
$$

where $f_{M e}=[M e] /([F e(I I)]+[F e(I I I)]+[N i]), f_{F e(I I)}+$ $f_{\mathrm{Fe}(\mathrm{III})}+f_{\mathrm{NI}}=1$ and $a_{\mathrm{Me}}+\mathrm{x}(\mathrm{OH})_{\mathrm{x}}$ is the a-value for the pure Me-brucite species. In order to determine the extent of cation substitution in green rust and LDHs in general it is of interest to quantitatively relate lattice values and composition. Using equation (1), the avalue for each sample was calculated using the molar ratios given in table 1 and was plotted as a function of the Ni fraction in the sample in figure 2 (squares) along with the measured XRD values. The a-values for $\mathrm{Ni}(\mathrm{OH})_{2}$ and $\mathrm{Fe}(\mathrm{OH})_{2}$ are assumed to be $0.3126 \mathrm{~nm}$ and $0.3262 \mathrm{~nm}$, respectively. The " $a$-value" for $\mathrm{Fe}(\mathrm{OH})_{3}$ is assumed to be $0.3015 \mathrm{~nm}$ which is the $\mathrm{Fe}(\mathrm{III})-\mathrm{Fe}(\mathrm{III})$ distance in edge-sharing Fe(III) octahedra in $\alpha-\mathrm{FeOOH}$ (Bernal et al., 1959). This is very close to the $a$-value $(0.3025 \mathrm{~nm})$ for the highenergy ferric green rust prepared by fast oxidation of hydroxychloride green rust (Refait et al., 2003b).

There is good agreement between the calculated and XRD $a$-value suggesting a quantitative relationship between composition and the $a$-value. Note that equation (1) predicts the $a$-value for GR2 at $0.3178 \mathrm{~nm}$, which is very close to the measured value of $0.3174 \mathrm{~nm}$. While it would be desirable to predict composition using only information of the cations present and the a-value, this is only possible in principle for a system consisting of two different cations. For a ternary system such as nickelous green rust, an additional relationship between the molar quantities of the constituents is required. However, in the case of GR2, where the divalent/trivalent cation ratio is generally accepted to be $2: 1$ (Hansen et al., 1994; Refait et al., 1999, 2005) $\left(f_{\mathrm{Fe}(\mathrm{OH})_{2}}=1 / 3\right)$, the avalue can be used in principle to quantitatively predict the extent of divalent cation substitutions for Fe(II). In the present case this leads to the following relationship between the measured a-value $\left(a_{N i-G R 2}\right)$ and the Ni fraction in the GR2 structure. 


$$
f_{\mathrm{Ni}}=\frac{a_{\mathrm{Ni}-\mathrm{GR} 2}-\frac{1}{3} a_{\mathrm{Fe}(\mathrm{OH})_{3}}-\frac{2}{3} a_{\mathrm{Fe}(\mathrm{OH})_{2}}}{a_{\mathrm{Ni}(\mathrm{OH})_{2}}-a_{\mathrm{Fe}(\mathrm{OH})_{2}}}
$$

In principle this relationship could be used to predict the extent of substitution of any divalent cation in the GR2 structure, provided the appropriate $a$-values are known.

\section{Effect of oxidation}

In order to determine the extent to which the $\mathrm{LDH}$ structure is retained on oxidation of the structural $\mathrm{Fe}(\mathrm{II})$ the samples were exposed to ambient air and then each sample was examined by XRD several times over a period of 7 to 45 days from the time of initial exposure. There was no significant change in the XRD patterns of the oxidized samples in this time interval. Figure 4 shows the XRD results for all samples after one month of exposure to oxidizing conditions; pure GR2 was included at the bottom of the figure as reference.

Samples prepared without Ni $(\mathrm{P}=100 / 0)$ and the lowest $\mathrm{Ni}$ concentration $(\mathrm{P}=90 / 10)$ oxidized quickly and turned from the initial green color to yellow brown. The LDH structure was lost and goethite and

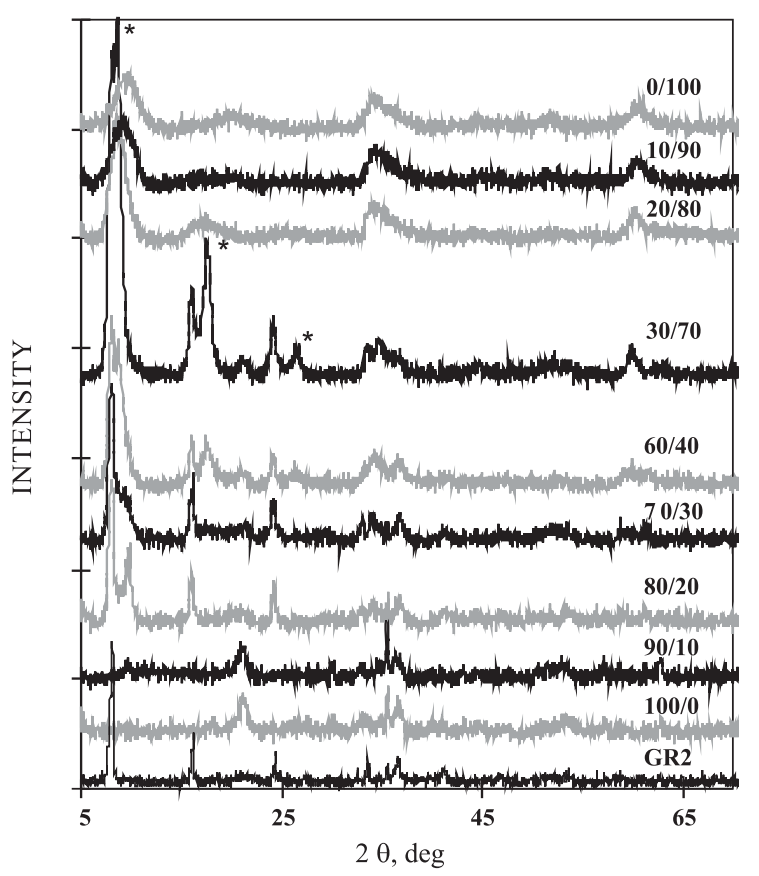

Figure 4. X ray diffraction patterns of the final products from the aerial oxidation of the dry $\mathrm{Ni}(\mathrm{II})-\mathrm{GR} 2$ samples as a function of the Fe(II)/ $\mathrm{Ni}$ (II) ratio of the starting solution. Asterisks denote the peak positions for a second $\mathrm{LDH}$ with c-value $1.013 \mathrm{~nm}$. Peaks for goethite $\left(2 \theta=21^{\circ}\right.$, $\left.33^{\circ}, 36.6^{\circ}, 53.2^{\circ}, 57.0^{\circ}\right)$ and magnetite $\left(2 \theta=30.1^{\circ}\right.$, $\left.35.5^{\circ}, 36.6^{\circ}, 53.2^{\circ}, 57.0^{\circ}, 62.7^{\circ}\right)$ were identified for samples 100/0 and 90/10. magnetite were identified based on the XRD pattern. The presence of goethite agrees with Olowe \& Genin (1991) who showed that goethite and lepidocrocite are expected GR2 oxidation products, depending on initial conditions. Magnetite was identified in the precipitation of the fresh GR2 sample prior to oxidation. On the contrary, samples with higher Ni content, $\mathrm{P}=$ 80/20, 70/30, 60/40 and 30/70, remained greenish. For these samples the three most intense peaks typifying green rust can be easily seen. As was shown for Ni(II)GR2 (Refait et al., 1990) all Fe(II) is transformed to $\mathrm{Fe}$ (III) and the oxidized LDHs contain only $\mathrm{Ni}$ (II) and $\mathrm{Fe}(\mathrm{III})$. In addition to the reference Ni(II)-Fe(III) $\mathrm{LDH}$ isomorphous with green rust $(c$-value $\sim 1.09 \mathrm{~nm})$ additional peaks are seen indicating the presence of other minerals. For $\mathrm{P}=80 / 20$ a peak appears at $2 \theta=$ 9.85 corresponding to a $d$-value of $0.926 \mathrm{~nm}$. This peak is still present for $\mathrm{P}=70 / 30$ but appears as a shoulder. It was not possible to detect the mineral inducing this peak. For samples $\mathrm{P}=60 / 40$ and $30 / 70$ the peak at $2 \theta=9.85^{\circ}$ was no longer present and three peaks appeared, each of which had shifted to the right of one of the main peaks associated with the reference $\mathrm{Ni}(\mathrm{II})-\mathrm{Fe}(\mathrm{III}) \mathrm{LDH}$ with c-value of $1.09 \mathrm{~nm}$. These peaks are marked with asterisks and correspond to an additional LDH with $c$-value $1.013 \mathrm{~nm}$ and $a$-value $0.3094 \mathrm{~nm}$. The reduction in $c$-value on exposure to air is probably due to dehydration. This is consistent with the fact that the LDHs honessite ( $c$-value $0.89 \mathrm{~nm}$ ) and hydrohonessite (c-value $1.09 \mathrm{~nm}$ ) only differ in the amount of water in the interlayer (Nickel $\&$ Wildman, 1981). This suggests the sample is a mixture of two Ni-Fe(III) LDHs which differ in the extent of dehydration. With further increase in $\mathrm{Ni}$ content $(\mathrm{P}=20 / 80,10 / 90$ and $0 / 100)$ the oxidized samples become poorly crystalline LDH phases.

\section{CONCLUSION}

Nickel is readily incorporated in the GR2 structure and forms a solid solution between GR2 and a Ni(II)Fe(III) LDH. There is a correlation between the unit cell $a$-value and the fraction of Ni(II) incorporated into the Ni(II)-GR2 structure. Since there is strong evidence that the divalent/trivalent cation ratio in GR2 is fixed at 2 , it is possible in principle to determine the extent of divalent cation substitution for $\mathrm{Fe}$ (II) in GR2 from the unit cell $a$-value. On oxidation a mixture of minerals are formed but the LDH structure is retained if at least $20 \%$ of the divalent cations in the initial solution are $\mathrm{Ni}(\mathrm{II})$. It appears $\mathrm{Ni}(\mathrm{II})$ is incorporated in a stable $\mathrm{LDH}$ structure. This is important for two reasons, first for understanding the formation of $\mathrm{LDHs}$, which are anion exchangers, in the natural environment. Secondly, this may be important for understanding the fate of transition metals in the environment, particularly in the presence of reduced Fe compounds. 


\section{ACKNOWLEDGEMENTS}

Lúcia Helena Garófalo Chaves thanks the departments of Agricultural and Biosystems Engineering and Soil Water and Environmental Science of the University of Arizona for support. The authors wish to thank Mary Kay Amistadi for assistance with the analytical instruments. They further acknowledge the Molecular Structure Laboratory and support from the NSF CHE9974726 for the diffractometer. This research was supported by NSF ITR Grant PHY0219411, the Petroleum Research Fund and Coordenação de Aperfeiçoamento de Pessoal de Nível Superior (CAPES), Brazil.

\section{LITERATURE CITED}

BARTZAS, G.; KOMNITSAS, K. \& PASPALIARIS, I. Laboratory evaluation of $\mathrm{Fe}^{0}$ barriers to treat acidic leachates. Miner. Eng., 19:505-514, 2006.

BERNAL, J.D.; DASGUPTA, D.R. \& MaCKAY, A.L. The oxides and hydroxides of iron and their structural interrelationships. Clay Miner. B., 4:15-30, 1959.

BISH, D.L. \& LIVINGSTONE, A. The crystal chemistry and paragenesis of honessite and hydrohonessite - The sulfate analogs of Reevesite. Miner. Mag., 44:339-343, 1981.

BOURRIÉ, G.; TROLARD, F.; REFAIT, Ph. \& FEDER, F. A solid-solution model for $\mathrm{Fe}(\mathrm{II})-\mathrm{Fe}$ (III)- $\mathrm{Mg}$ (II) green rusts and fougerite and estimation of their gibbs free energies of formation. Clays Clay Miner., 52:382-394, 2004.

CARVALHO E SILVA, M.L.; RAMOS, A.Y.; TOLENTINO, H.C.N.; ENZWEILER, J.; NETTO, S.M. \& ALVES, M.D.C.M. Incorporation of $\mathrm{Ni}$ into natural goethite: $\mathrm{An}$ investigation by $\mathrm{X}$ ray absorption spectroscopy. Am. Miner., 88:876-882, 2003.

CHAVES, L.H.G.; CURRY, J.E.; STONE, D.A. \& CHOROVER, J. Fate of nickel ion in (II-III) hydroxysulphate green rust synthesized by precipitation and coprecipitation. R. Bras. Ci. Solo, 31:813-818, 2007.

CHUNG, K.W.; KHO, Y.T. \& KIM, K.B. Oxidation behavior of $\mathrm{Ni}_{\mathrm{x}} \mathrm{Fe}_{1-\mathrm{x}}(\mathrm{OH})_{2}$ in $\mathrm{Cl}^{-}$containing solution. Corros. Sci., 44:2757-2775, 2002

CORNELL, R.M.; GIOVANOLI, R. \& SCHNEIDER, W. The effect of nickel on the conversion of amorphous iron (III) hydroxide into more crystalline iron oxides in alkaline media. J. Chem. Technol. Biotechnol., 53:73-79, 1992.

DRITS, V.A. \& BOOKIN, A.S. Crystal structure and X ray identification of layered double hydroxides. In: RIVES, V., ed. Layered double hydroxides: Present and future. New York, Nova Science, 2001. p.39-92.

FORD, R.G.; KEMNER, K.M. \& BERTSCH, P.M. Influence of sorbate-sorbent interactions on the crystallization kinetics of nickel - and lead-ferrihydrite coprecipitates. Geochem. Cosmochem. Acta, 63:39-48, 1999.
FROST, R.L.; WEIER, M.L.; CLISSOLD, M.E.; WILLIAMS, P.A. \& KLOPROGGE, J.T. Thermal decomposition of the natural hydrotalcites carrboydite and hydrohonessite. Thermochem. Acta, 407:1-9, 2003.

GÉHIN, A.; RUBY, C.; ABDELMOULA, M.; BENALI, O.; GHANBAJA, J.; REFAIT, Ph. \& GÉNIN, J.M.R. Synthesis of Fe(II-III) hydroxysulphate green rust by coprecipitation. Solid State Sci., 4:61-66, 2002.

GÉNIN, J.M.R. Fe(II-III) Hydroxysalt green rusts; from corrosion to mineralogy and abiotic to biotic reactions by Mössbauer spectroscopy. Hyper. Interac., 156/157:471485,2004

GÉNIN, J.M.R.; REFAIT, Ph.; BOURRIÉ, G.; ABDELMOULA, M. \& TROLARD, F. Structure and stability of the Fe(II)Fe(III) green rust "fougerite" mineral and its potential for reducing pollutants in soil solution. Appl. Geochem., $16: 559-570,2001$

GOPALAN, P. \& KAHR, B. Reevaluating structures for mixed crystals of simple isomorphous salts, $\mathrm{Ba}_{\mathrm{x}} \mathrm{Pb}_{1-\mathrm{x}}\left(\mathrm{NO}_{3}\right)_{2}$. J. Solid State Chem., 107:563-567, 1993.

GREAVES, C. \& THOMAS, M.A. Refinement of the structure of deuterated nickel hydroxide, $\mathrm{Ni}(\mathrm{OD}) 2$, by powder neutron diffraction and evidence for structural disorder in samples with high surface area. Acta Crystallogr. B Structural Sci., 42:51-55, 1986.

HANSEN, H.C.B.; BORGGAARD, O.K. \& SORENSEN, J, Evaluation of the free energy of formation of $\mathrm{Fe}(\mathrm{II})$-Fe(III) hydroxide-sulfate (green rust) and its reduction of nitrite. Geochem. Cosmochem. Acta, 58:2599-2608, 1994.

HANSEN, H.C.B.; GULDBERG, S.; ERBS, M. \& KOCH, C.B. Kinetics of nitrate reduction by green rusts - effects of interlayer anion and Fe(II): Fe(III) ratio. Appl. Clay Sci., 18:81-91, 2001.

INOUE, K.; SHINODA, K.; SUZUKI, S. \& WASEDA, Y. Characteristic behavior of nickel ions during transformation of green rust to ferric oxyhydroxides in aqueous solution. Mater. Trans., 49:466-470, 2008.

LIN, R.G.; SPICER, R.L.; TUNGATE, F.L. \& DAVIS, B.H. A study of the oxidation of ferrous hydroxide in slightly basic solution to produce gamma-FeOOH. Colloids Surf. A-Physicochem. Engin. Aspects, 113:79-96, 1996.

LOYAUX-LAWNICZAK, S.; REFAIT, PH.; EHRHARDT, J.J.; LECOMTE, P. \& GÉNIN, J.M.R. Trapping of Cr by formation of ferrihydrite during the reduction of chromate ions by $\mathrm{Fe}(\mathrm{II})-\mathrm{Fe}(\mathrm{III})$ hydroxysalt green rusts. Environ. Sci. Technol., 34:438-443, 2000.

MANCEAU, A.; SCHLEGEL, M.L.; MUSSO, M.; SOLE, V.A.; GAUTHIER, C.; PETIT, P.E. \& TROLARD, F. Crystal chemistry of trace elements in natural and synthetic goethite. Geochem. Cosmochem. Acta, 64:3543-3661, 2000 .

NICKEL, E.H. \& WILDMAN, J.E. Hydrohonessite - A new hydrated Ni-Fe hydroxy-sulfate mineral - its relationship to honessite, carrboydite, and minerals of the pyroaurite group. Mineral. Mag., 44:333-337, 1981. 
OLOWE, A.A. \& GÉNIN, J.M.R. The mechanism of oxidation of ferrous hydroxide in sulphated aqueous media: Importance of the initial ratio of the reactants. Corros. Sci., 32:965-984, 1991

PARMAR, N.; GORBY, Y.A.; BEVERIDGE, T.J. \& FERRIS, F.G. Formation of green rust and immobilization of nickel in response to bacterial reduction of hydrous ferric oxide. Geomicrob. J., 18:375-385, 2001.

REFAIT, Ph.; ABDELMOULA, M. \& GÉNIN, J.M.R. Oxidation of pyroaurite-like Ni-Fe hydroxychlorides studied by Mössbauer spectroscopy at $16 \mathrm{~K}$. Clay Miner., 33:665669, 1998.

REFAIT, Ph.; ABDELMOULA, M.; SIMON, L. \& GÉNIN, J.M.R. Mechanisms of formation and transformation of Ni-Fe layered double hydroxides in $\mathrm{SO}_{3}{ }^{2-}$ and $\mathrm{SO}_{4}{ }^{2-}$ containing aqueous solutions. J. Physics Chem. Solids, 66:911-917, 2005.

REFAIT, Ph.; BAUER, PH.; OLOWE, A.A. \& GÉNIN, J.M.R The substitution of $\mathrm{Fe}^{2+}$ ions by $\mathrm{Ni}^{2+}$ ions in the green rust 2 compound studied by Mössbauer effect. Hyper. Interac., 57:2061-2066, 1990.

REFAIT, Ph.; BENALI, O.; ABDELMOULA, M. \& GÉNIN, J.M.R. Formation of 'ferric green rust' and/or ferrihydrite by fast oxidation of iron(II-III) hydroxychloride green rust. Corros. Sci., 45:2435-2449, 2003b.

REFAIT, Ph.; BON, C.; SIMON, L.; BOURRIÉ, G.; TROLARD, F.; BESSIÉRE, J. \& GÉNIN, J.M.R. Chemical composition and Gibbs standard free energy of formation of $\mathrm{Fe}(\mathrm{II})$ $\mathrm{Fe}(\mathrm{III})$ hydroxysulphate green rust and $\mathrm{Fe}(\mathrm{II})$ hydroxide. Clay Miner., 34:499-510, 1999.

REFAIT, Ph. \& GÉNIN, J.M.R. The oxidation of Ni(II)-Fe(II) hydroxides in chloride-containing aqueous media. Corros. Sci., 34:2059-2070, 1993.
REFAIT, Ph. \& GÉNIN, J.M.R. Mechanisms of oxidation of $\mathrm{Ni}(\mathrm{II})-\mathrm{Fe}(\mathrm{II})$ hydroxides in chloride-containing aqueous media: Role of the pyroaurite-type Ni-Fe hydroxychlorides. Clay Miner., 32:597-613, 1997.

REFAIT, Ph.; DRISSI, H.; MARIE, Y. \& GÉNIN, J.M.R. The substitution of $\mathrm{Fe}^{2+}$ ions by $\mathrm{Ni}^{2+}$ ions in green rust one compounds. Hyper. Interac., 90:389-394, 1994.

REFAIT, Ph.; MEMET, J.B.; BON, C.; SABOT, R. \& GÉNIN, J.M.R. Formation of the $\mathrm{Fe}(\mathrm{II})$ - $\mathrm{Fe}(\mathrm{III})$ hydroxysulphate green rust during marine corrosion of steel. Corros. Sci., 45:833-845, 2003a.

RIVES, V. Layered double hydroxides: Present and future. New York, Nova Science, 2001.

SINGH B.; SHERMAN D.M.; GILKES R.J.; WELLS, M.A. \& MOSSELMANS, J.F.W. Incorporation of $\mathrm{Cr}, \mathrm{Mn}$ and $\mathrm{Ni}$ into goethite (a-FeOOH): Mechanism from extended $\mathrm{X}$ ray absorption fine structure spectroscopy. Clay Miner., 37:639-649, 2002.

STOOKEY, L.L. Ferrozine - a new spectrophotometric reagent for iron. Anal. Chem., 42:779-782, 1970.

TICHIT, D.; DAS, N.; COQ, B. \& DURAND, R. Preparation of Zr-containing layered double hydroxides and characterization of the acido-basic properties of their mixed oxides. Chem. Mater., 14:1530-1538, 2002.

VEGARD, L. The constitution of the mixed crystals and the filling of space of the atoms. Zeitschrift für Physik, 5:1726, 1921.

WAMBACH J.; WOKAUN A. \& HILTPOLD, A. Oxidation of stainless steel under dry and aqueous conditions: Oxidation behaviour and composition. Surf. Interf. Anal., 34:164-170, 2002. 